\title{
Supply Chain of Organic Salak Pondoh (Salacca zalacca var.pondoh) in Pagar Alam City- South Sumatera Province
}

\author{
Herfiani Rizkia ${ }^{1}$, Wahyu Anita Sari ${ }^{2}$ \\ ${ }^{1}$ Research Development and Innovation Board of South Sumatera Province. \\ Jl. Demang LebarDaunNo.4864 Palembang, zip-code 30137 \\ E-mail: herfiani74@gmail.com
}

${ }^{2}$ Departement of Agriculture Food Crops and Horticulture of South Sumatera Province Jl. Kapten Piere Tendean No. 1058 Palembang, zip-code 30129

E-mail: wahyu anitasari@hotmail.com,disperta-sumsel@yahoo.co.id

\begin{abstract}
This study is a continued research of sertification of Salak var. Pondoh in Pagar Alam. This aim of this study is to get informations about characteristic and condition of organik Salak var. pondoh supply chain in Pagar Alam City, South Sumatera. In year 2012, the Sertification organic agencies (LSO) of West Sumatera have delivered organic sertification to about 5 ha land area of Salak var pondoh of Dempo's farmer group. Since that time, the production of an organic Salak pondoh in Pagar Alam city increased every year, from 1.27ton per year in 2011 become 1.42 ton per year in 2013 for every $0.25 \mathrm{Ha}$ of land area. The price of organic salak var. Pondoh Pagar Alam ranged from IDR 5000 until IDR 12000 at level of farmer and from 10000 until IDR 15000 in level of consumers. The actor in Supply chain of organic Salak var.pondoh in Pagar Alam, covering : farmer, group of farmer, distributor, and or outlet (a place of bussiness for retailing salak), and retailer/domestic consumers). The activities along the supply chain of Salak var. Pondoh in Pagar Alam covering : harvesting, collecting and shelters of harvest, cleaning, sortation, grading and distribution.
\end{abstract}

Keywords— Salak Pondoh (Salacca zalacca var. pondoh), supply chain, organic sertification.

\section{INTRODUCTION}

Salak is an Indonesia tropical fruit which is very popular in Indonesia. The center planting of Salak in Indonesia are West Java (Manonjaya and Salawu), Yogyakarta (Sleman and Tempel), East Java (Sacah, Walingi and Karangsari), Nort Sumatera (Padang Sidempuan), Nort Sulawesi (Sangir Talaud), Bali (karangasem) and also Lombok island. Various kinds of superior salak varieties grown in Indonesia, namely Salak var. Jawa (Salacca zalacca), salak var. Bali (Salacca amboinensis), Salak var. Padang Sidempuan (Salacca sumatrana) [1], Salak var Pondoh, Swaru, Nglumut, Enrekang and Sugar Stone [2]. At the present, Indonesia has more than 17 superior varieties [2]. In several regions in Indonesia, such as Java, Sumatera, and Bali, Salak is main source of farmers income.

Salak fruit grows well in the lowlands up to an altitude of $700 \mathrm{~m}$ above sea level (asl) with an average rainfall of 200$400 \mathrm{~mm}$ per year per month. The plant of Salak grow well at fertile soil, crumbly, and moist, and degree of soil acidity $(\mathrm{pH})$ of 4.5 to 7.5 .

Generally, Salak is consumed as fresh fruit because it contain high nutrition, rich in fiber and minerals. Per $100 \mathrm{~g}$ part of salak contain of $0.77 \mathrm{~g}$ of calorie, $0.4 \mathrm{~g}$ of protein, 21 , $9 \mathrm{mg}$ of carbohydrate, $2.8 \mathrm{~g}$ of calsium, $1.8 \mathrm{mg}$ of fosfor, 4.2 $\mathrm{mg}$ zof zinc, various vitamin and $78 \mathrm{~g}$ of water.

Salak var. Pondoh is a populer superior variety because of the taste is sweet, crisp and smell good. The fruit consist of three fruit pulp parts in white; fruit flesh thickness is about $0.8-1.5 \mathrm{~cm}$; weigh is about $30-100 \mathrm{~g}$ per fruit; and diameter is about $2.5-2.7 \mathrm{~cm}$ per fruit [1]

Salak var. Pondoh is also cultivated in South Sumatera, especially in Pagar Alam (as shown in Fig 1) city where the area is a plateau with an altitude of 705-870 asl latosol soil type and andosol.

Salak var. pondoh in Pagar Alam also cultivated organically; by using natural fertilizers and no pesticides or insecticides. So that causes the salak var. pondoh in Pagar Alam City is preferred by local consumers and visitors tour of Mount Dempo. The cultivation of organic Salak var. pondoh in Pagar Alam is an provincial goverment effort to improve the quality of food and meet the needs of consumers on products which is safe and health. 


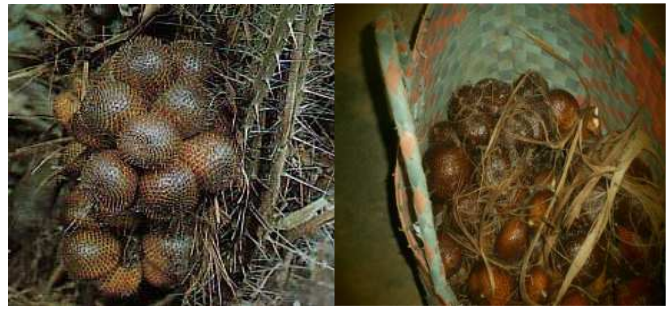

Fig. 1. Salak Pondoh (Salacca zalacca var. Pondoh) Pagar Alam

Nowadays, the production of organic salak salak in Pagar Alam is still limited and can only meet the needs of local consumers. Because of that, it required managing the flow of goods and service named supply chain. Supply chain is a concept that describes the chain of supply flow of material, information and money from the upstream side or the raw material to the downstream side or finished goods [3]. Also, can be said that the supply chain involves all the activities in order to meet the needs of consumers.

To manage the flow of goods and services in the supply chain, first of all there is to know is the true and complete picture of the entire existing chain, ranging from the first to the last one. Especially, for fresh agriculture product, it have supply chain more complex than others supply chain because of their characteristics such as : perishable, seasonal, varied in quality, lose of freshness, and obsolescence.

\section{METHOD}

The method used was a qualitative descriptive of the recent condition of the supply chain in Pagar Alam city of South Sumatera province that is by doing eksploration the supply chain of Organic Salak var. Pondoh in Pagar Alam.

\section{Place and Time}

The study was conducted in 2013 at the location farmer group of Salak var.pondoh, Pagar Alam-South Sumatra Province. Salak pondoh farmer group in Pagar Alam has 12 farmer as a member which is 5 farmer have implement organic cultivation system in producing salak var.pondoh. because of that, it took 5 location land area of salak var.pondoh in Pagar Alam which is sertified organically, namely : farmer $\mathrm{A}=1 \mathrm{Ha}$; farmer $\mathrm{B}=3 \mathrm{Ha}$; farmer $\mathrm{C}=0.5$ $\mathrm{Ha}$; farmer $\mathrm{D}=0.25 \mathrm{Ha}$; and farmer $\mathrm{E}=0.25 \mathrm{Ha}$.

\section{Data and Information}

To explore the conditions of the supply chain of organic Salak var.pondoh was carried out data collection and information from experts (personnel department of agriculture of Pagar Alam) and respondent (5 members Salak Dempo's farmers group). Primary data were obtained either directly from the field using a structured questionnaire tool and also un-structured in-depth interviews. Secondary data were obtained from literature and various other scientific publications as well as tracking data from a variety of sources.

\section{RESULTS AND DISCUSSION}

Potential and Production of Organic Salak var. Pondoh in Pagar Alam

Productivity of land area of organic var.pondoh in Pagar Alam which has passed organic certification, increase from year to year (as shown in Table 1)

TABLE I

PRODUCTION OF ORGANIC SALAK VAR.PONDOH

\begin{tabular}{|c|r|r|r|r|}
\hline \multirow{2}{*}{ Farmer } & \multirow{2}{*}{ Land area (ha) } & \multicolumn{3}{|c|}{ Production (ton per year) } \\
\cline { 3 - 5 } & & $\mathbf{2 0 1 1}$ & $\mathbf{2 0 1 2}$ & $\mathbf{2 0 1 3}$ \\
\hline A & 1 & 6.20 & 6.70 & 6.9 \\
\hline B & 3 & 18.90 & 18.90 & 20.1 \\
\hline C & 0,5 & 2.10 & 2.30 & 2.45 \\
\hline D & 0,25 & 1.08 & 1.15 & 1.2 \\
\hline E & 0,25 & 1,08 & 1.13 & 1.28 \\
\hline \multicolumn{2}{|c|}{ Total productions } & $\mathbf{2 9 . 3 5}$ & $\mathbf{3 0 . 1 8}$ & $\mathbf{3 2 . 0 0}$ \\
\hline
\end{tabular}

Elemen of Supply Chain of Organic Salak var.Pondoh Pagar Alam

[4] described there are three element in supply chain, namely : facilities, function, and activities. Elemen in supply chain of organic salak var.pondoh, Pagar Alam as shown in Fig 2.

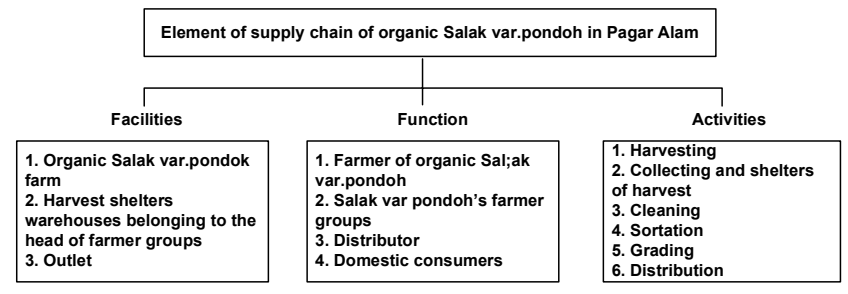

Fig. 2. Element in Supply Chain of Organic Salak var. Pondoh in Pagar Alam

The facilities needed in supply chain of organic Salak var.pondoh is a organic salak land area as a plant which produced organic salak var.pondoh; warehouse belonging chairman of farmer group of organic salak var.pondoh as a temporary warehouse and also as a packing house.

The functions as a production and distribution organic salak var.pondoh are starting from farm to end consumers which done by organic salak var. Pondoh supply chain actors. An organic salak var.pondoh supply chain can describe in Fig 3.

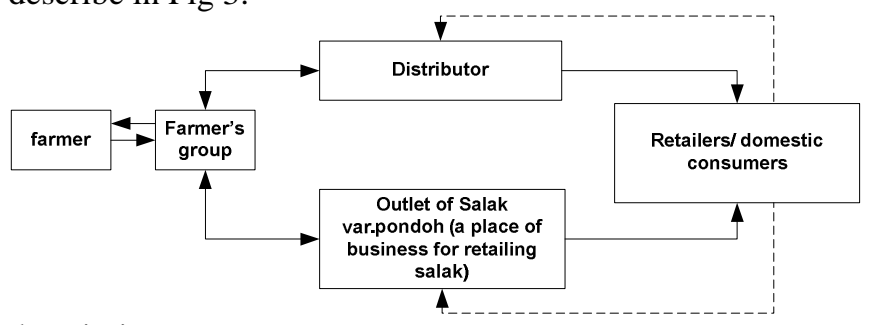

description :

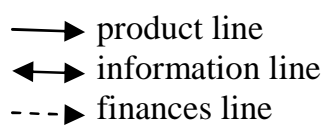

Fig. 3. Supply Chain of Organic Salak var. Pondoh in Pagar Alam 
The activities along the supply chain of Salak var. Pondoh in Pagar Alam covering : harvesting, collecting and shelters of harvest, cleaning, sortation, grading and distribution. the Supply chain issues in farmer groups (Poktan) Salak Dempo Pagar Alam is a limited availability of raw materials, high demand for organic Salak var.pondoh and bad practice in determine harvesting age (harvest before the best age harvest).

Sortation and storage activities has not been done by farmer of organic Salak var.pondoh. Sortation, grading, storage and other postharvest activities done at the head of a group of farmers and distributors. Sortation is done based on disability. Grading is done based on weight of the desired size, in order to obtain classification organic salak var. Pondoh into quality class namely : grade A, B and C. The price of organic salak salak var. Pondoh depend on the class of its quality (as shown in Table 2).

TABLE II

PRODUCTION OF ORGANIC SALAK VAR.PONDOH IN PAGAR ALAM-SOUTH SUMATERA

\begin{tabular}{|c|c|r|r|c|}
\hline $\begin{array}{c}\text { Class of } \\
\text { quality } \\
\text { (Grade) }\end{array}$ & $\begin{array}{c}\text { Weight of } \\
\text { each (g) }\end{array}$ & $\begin{array}{c}\text { Price at } \\
\text { farmer } \\
\text { level } \\
\text { (IDR/kg) }\end{array}$ & $\begin{array}{c}\text { Price at } \\
\text { consumer } \\
\text { level } \\
\text { (IDR/kg) }\end{array}$ & Description \\
\hline A & $50-54$ & 12000 & 15000 & Super \\
\hline B & $40-49$ & 8000 & 13000 & Standard \\
\hline C & $30-39$ & 5000 & 10000 & Small \\
\hline
\end{tabular}

The next step, best quality of organic salak var.pondoh is distributed to distributor and also sent to outlet Salak Dempo in Pagar Alam city. Organic salak var. Pondoh that does not meet the criteria of quality, immediately processed into food namely "dodol salak"

\section{CONCLUSIONS}

The actor in Supply chain of organic Salak var.pondoh in Pagar Alam, covering : farmer, group of farmer, distributor, and or outlet (a place of bussiness for retailing salak), and retailer/domestic consumers. The activities along the supply chain of Salak var. Pondoh in Pagar Alam covering : harvesting, collecting and shelters of harvest, cleaning, sortation, grading and distribution.

\section{ACKNOWLEDGMENT}

We would like to thank to : (1) Department of Agriculture Food Crops and Horticulture of South Sumatra Province that has been granted permission for author to write and publish this study; (2) research development and innovation board of South Sumatera province; (3) the goverment of Pagar Alam; (4) department of agriculture of Pagar Alam; (5) Mr. Endang Effendi as a chaiman of farmer group Salak Dempo; and (6) members of farmer group Salak Dempo of Pagar Alam

\section{REFERENCES}

[1] Agromedia. Budidaya Tanaman Buah Unggul Indonesia.2009. PT Agromedia Pustaka.

[2] Karya Tani Mandiri.Pedoman Budi Daya Buah Salak. 2010.

[3[ Indrajit, RE and R. Djokopranoto in Marimin and N. Maghfiroh. Aplikasi Teknik Pengambilan keputusan dalam Manajemen Rantai Pasok. 2010. IPB Press

[4] Ma'arif, M.S and Tanjung H. Manajemen Operasi. 2003. PT.Gramedia Jakarta 